\title{
Upaya Peningkatan Motivasi dan Kemampuan Membaca Permulaan Melalui Media Kartu Huruf Pada Siswa Kelas 1 SD Negeri 1 Pakis Kecamatan Kradenan Tahun Pelajaran 2017/2018
}

\author{
Sri Sunarti \\ srisunartipks1@gmail.com \\ SD Negeri 1 Pakis
}

\begin{abstract}
Abstrak
Permasalahan utama pada penelitian ini adalah rendahnya kemampuan membaca permulaan siswa kelas I SD Negeri 1 Pakis pada mata pelajaran Bahasa Indonesia. Salah satu faktor yang menyebabkan kemampuan membaca siswa rendah adalah proses pembelajaran masih menggunakan media konvensional yaitu dengan menggunakan papan tulis dan pembelajaran hanya berpusat kepada guru serta membuat siswa pasif. Tujuan penelitian yang akan dicapai adalah untuk mengetahui apakah media kartu huruf dapat meningkatkan motivasi dan kemapuan membaca permulaan di kelas I SD Negeri 1 Pakis Kecamatan Kradenan Kabupaten Grobogan. Variabel yang menjadi sasaran perubahan dalam penelitian tindakan kelas ini adalah meningkatkan motivasi dan kemampuan membaca permulaan siswa kelas I SD, sedangkan variabel tindakan yang digunakan dalam penelitian ini adalah media kartu huruf. Penelitian Tindakan Kelas ini dilaksanakan dua siklus dengan jumlah siswa 25 orang, setiap siklus terdiri dari perencanaan pelaksanaan tindakan, observasi dan refleksi. Dari hasil tindakan siklus I diperoleh hasil belajar membaca permulaan siswa dengan nilai rata-ratanya 69 dengan presentase siswa $52 \%$. Hasil tindakan siklus II diperoleh hasil belajar membaca permulaan siswa dengan nilai rata-ratanya 78,67 dengan presentase siswa 92\%. Dengan demikian dapat disimpulkan pembelajaran Bahasa Indonesia (membaca permulaan) dengan penggunaan media kartu huruf dapat meingkatkan kemampuan membaca permulaan di kelas I SD Negeri Pakis Kecamatan Kradenan Kabupaten Grobogan.
\end{abstract}

Kata Kunci: Membaca permulaan, Media Kartu Huruf.

\section{Pendahuluan}

Membaca merupakan suatu aktivitas yang dilakukan untuk mendapatkan sebuah informasi, memperoleh ilmu dan pengetahuan serta pengalaman baru. Pada hakikatnya, aktivitas membaca terdiri dari dua bagian, yaitu membaca sebagai proses dan membaca sebagai produk. Membaca sebagai proses mengacu pada aktivitas fisik dan mental. Sedangkan membaca sebagai produk mengacu pada konsekuensi dari aktivitas yang dilakukan pada saat membaca ( Puji Santosa dkk, 2005: 6.3).

Kegiatan membaca merupakan aktivitas yang unik dan rumit, sehingga seseorang tidak dapat melakukan hal tersebut tanpa mempelajarinya, terutama anak usia sekolah dasar yang baru mengenal huruf atau kata-kata. Problem umum yang dihadapi anak dalam membaca adalah pada pelaksanaan pengajaran membaca, guru sering kali dihadapkan anak yang mengalami kesulitan, baik yang berkenaan dengan hubungan huruf, suku kata, kata, kalimat sederhana, maupun ketidakmampuan anak memahami isi bacaan.

Berdasarkan Kurikulum Berbasis Kompetensi Bahasa Indonesia 2004, Standar Kompetensi Mata Pelajaran Bahasa Indonesia khususnya membaca permulaan, siswa dituntut untuk mampu membaca huruf, suku kata dan kalimat. Pembelajaran di SD dilaksanakan sesuai dengan perbedaan atas kelas rendah dan kelas tinggi. Pelajaran di kelas rendah biasanya disebut pelajaran membaca permulaan, sedangkan dikelas tinggi disebut pelajaran membaca lanjut.

Penggunaan model pembelajaran dan media sangat membantu dalam pengajaran membaca permulaan bagi siswa kelas satu SD merupakan hal yang mutlak diperlukan, anak kelas satu SD yang pada umumnya baru berusia enam tahun masih berada pada taraf berfikir konkret, yaitu anak akan mudah mengenali hal-hal yang bersifat nyata. Disamping itu, dengan alat bantu yang digunakan oleh guru secara bervariasi akan membangkitkan minat siswa dalam mengikuti pelajaran. Salah satu media yang memungkinkan digunakan oleh guru dalam pengajaran membaca permulaan ini adalah melalui media 
kartuhuruf.

Pembelajaran membaca permulaan di SD Negeri 1 Pakis Kecamatan Kradenan selama ini masih belum mengoptimalkan media pembelajaran yang ada di sekolah. Proses pembelajaran masih menggunakan media konvensional yaitu dengan menggunakan papan tulis dan pembelajaran hanya berpusat kepada guru. Hal ini menyebabkan motivasi dan kemampuan membaca permulaan siswa masih sangat rendah. Media Kartu Huruf yang ada di sekolah tidak dipergunakan sebagaimana mestinya dan hanya disimpan dalam lemari.

Dari uraian latar belakang di atas, peneliti tertarik untuk mengadakan penelitian tindakan kelas dengan judul "Upaya Peningkatan Motivasi dan Kemampuan Membaca Permulaan melalui Media Kartu Huruf Pada Siswa Kelas I SD Negeri 1 Pakis Kecamatan Kradenan Tahun Pelajaran 2017/2018”.

\section{Pengertian Membaca Permulaan}

Membaca merupakan proses pengolahan bacaan secara kritis kreatif dengan tujuan memperoleh pemahaman secara menyeluruh tentang suatu bacaan, serta penilaian terhadap keadaan, nilai, dan dampak bacaan. Kegiatan membaca merupakan aktivitas mental memahami apa yang disampaikan penulis melalui teks atau bacaan.

Membaca Permulaan merupakan tahapan proses belajar membaca bagi siswa sekolah dasar kelas awal. Siswa belajar untuk memperoleh kemampuan dan menguasai teknik-teknik membaca dan menangkap isi bacaan dengan baik. Oleh karena itu guru perlu merancang pembelajaran membaca dengan baik sehingga mampu menumbuhkan kebiasan membaca sebagai suatu yang menyenangkan.

Pada tingkatan membaca permulaan, pembaca belum memiliki keterampilan kemampuan membaca yang sesungguhnya, tetapi masih dalam tahap belajar untuk memperoleh keterampilan atau kemampuan membaca. Membaca pada tingkatan ini merupakan kegiatan belajar mengenal bahasa tulis. Melalui tulisan itulah siswa dituntut dapat menyuarakan lambang-lambang bunyi bahasa tersebut, untuk memperoleh kemampuan membaca diperlukan tiga syarat, yaitu kemampuan membunyikan:

1. Lambang-lambang tulis,

2. Penguasaan kosakata untuk memberi arti, dan

3. Memasukkan makna dalam kemahiran bahasa.

Pelaksanaan membaca permulaan di kelas I sekolah dasar dilakukan dalam dua tahap, yaitu membaca periode tanpa buku dan membaca dengan menggunakan buku. Pembelajaran membaca tanpa buku dilakukan dengan cara mengajar dengan menggunakan media atau alat peraga selain buku misalnya kartu gambar, kartu huruf, kartu kata dan kartu kalimat. Pembelajaran membaca dengan buku merupakan kegiatan membaca dengan menggunakan buku sebagai bahan pelajaran.

Metode Yang Digunakan Dalam Pembelajaran Membaca Permulaan ada beberapa metode yang digunakan antara lain:1.Metode Eja, 2.Metode Bunyi dan Abjad, 3.Metode Suku Kata, 4.Metode Global, 5.Metode SAS (Struktural Analitik Sintetik)

\section{Media Pembelajaran}

Media pembelajaran secara umum adalah alat bantu proses belajar mengajar. Segala sesuatu yang dapat dipergunakan untuk merangsang pikiran, perasaan, perhatian dan kemampuan atau keterampilan belajar sehingga dapat mendorong terjadinya proses belajar. Batasan ini cukup luas dan mendalam mencakup pengertian sumber, lingkungan, manusia dan metode yang dimanfaatkan untuk tujuan pembelajaran/pelatihan.

Media pembelajaran adalah sarana fisik untuk menyampaikan isi/materi pembelajaran seperti : buku, film, video dan sebagainya (Briggs, 1977 dalam http://belajarpsikologi.com). Media juga seringkali diartikan sebagai alat yang dapat dilihat dan didengar. Alat-alat ini dipakai dalam pengajaran dengan maksud untuk membuat cara berkomunikasi lebih efektif dan efisien. Dengan menggunakan alat-alat ini, guru dan siswa dapat berkomunikasi lebih mantap, hidup dan interaksinya bersifat banyak arah.

\section{Alat Peraga Kartu huruf}

Alat adalah sarana yang sangat diperlukan dalam usaha menunjang keberhasilan suatu proses belajar mengajar. Alat peraga menurut Depdiknas (2003) adalah benda atau alat yang digunakan untuk 
memperagakan suatu fakta, konsep, prinsip/prosedur tertentu agar tampak lebih nyata/kongkret. Jadi Alat Peraga adalah sarana yang digunakan oleh guru untuk menunjang proses belajar mengajar didalam kelas agar pembelajaran itu tampak lebih nyata/kongkret sehingga siswa lebih mengerti.

Kartu huruf merupakan abjad-abjad yang dituliskan pada potongan- potongan suatu media, baik karton, kertas maupun papan tulis (tripleks). Potongan-potongan huruf tersebut dapat dipindah-pindahkan sesuai keinginan pembuat suku kata, kata maupun kalimat. Penggunaan kartu huruf ini sangat menarik perhatian siswa dan sangat mudah digunakan dalam pengajaran membaca permulaan. Selain itu kartu huruf juga melatih kreatifitas siswa dalam menyusun kata-kata sesuai dengan keinginannya.

\section{Metode Penelitian}

Penelitian tindakan kelas adalah penelitian yang melibatkan guru sebagai peneliti dalam meningkatkan dan memperbaiki masalah-masalah pada proses pembelajaran siswa di kelas dengan membuat rencana terlebih dahulu, kemudian melaksanakan, mengamati dan memberi refleksi tindakan terhadap kegiatan melalui siklus.

Model rancangan yang akan dikembangkan dalam penelitian ini adalah model spiral dari siklus yang satu ke siklus berikutnya oleh Kemmis dan McTaggart. Model yang dikemukakan oleh Kemmis dan McTaggart pada hakekatnya berupa perangkat-perangkat atau untaian-untaian dengan satu perangkat terdiri dari empat komponen, yaitu; perencanaan (Planning), tindakan (Action), pengamatan (Observation) dan refleksi (Reflection). Penelitian dilaksanakan di SD Negeri Pakis Kecamatan Kradenan Kabupaten Grobogan di kelas I tahun pelajaran 2017/2018. Penelitian ini dilakukan pada bulan Juli sampai dengan Oktober 2017.

Subjek penelitian ini adalah siswa kelas I sebanyak 25 siswa yang terdiri dari 11 siswa laki-laki dan 14 siswa perempuan. Penelitian ini dilaksanakan di SD Negeri 1 Pakis. Adapun yang menjadi variabel penelitian ini adalah sebagai berikut: 1. Variabel bebas dalam penelitian ini adalah penggunaan media kartu huruf. 2. Variabel terikat dalam penelitian ini adalah peningkatan motivasi dan kemampuan membaca. Sumber data yaitu aspek penelitian yang dapat memberikan informasi yang dapat membantu perluasan teori. Sumber data dalam penelitian.

\section{Hasil Dan Penelitian Hasil Tes Awal}

Penelitian ini dilakukan di kelas I SD Negeri Pakis Kecamatan Kradenan Kabupaten Grobogan Tahun Pelajaran 2017/2018. Pelaksanaan tindakan kelas ini terdiri dari dua siklus, setiap siklus meliputi empat tahapan yakni perencanaan tindakan, pelaksanaan tindakan, observasi, dan refleksi. Sebelum pelaksanaan tindakan kelas, dilakukan tes kemampuan awal untuk mengetahui kemampuan awal siswa tentang membaca permulaan. Berdasarkan hasil tes kemampuan awal diketahui bahwa kemampuan membaca permulaan siswa masih rendah. Hasil Tes kemampuan membaca permulaan pada kondisi awal sebelum pelaksanaan tindakan dengan nilai rata-rata perolehan 61 dan ketuntasan belajar klasikal $24 \%$.

\section{Siklus I}

Perencanaan yang dilakukan pada siklus I yakni menyusun perangkat pembelajaran, merencanakan tujuan pembelajaran, menyiapkan alat dan bahan ajar serta instrument penelitian yang meliputi evaluasi akhir tindakan, lembar observasi kegiatan guru dan siswa, dengan tujuan meningkatkan kemampuan membaca permulaan siswa kelas 1 melalui media kartu huruf. Pada kegiatan pembelajaran masih ada siswa yang tidak memperhatikan penjelasan guru dan asyik bermain dengan teman sebangku sehingga menggangu teman yang lain. Hal ini berakibat kurangnya konsentrasi teman yang lain dalam kegiatan pembelajaran. Pelaporan hasil atau presentasi masih ada beberapa siswa kurang berani mengeluarkan pendapat sehingga untuk mengatasi hal ini guru harus selalu memberi semangat agar dapat membangkitkan keberanian siswa

\section{Hasil observasi terhadap aktivitas guru dan siswa}

Hasil pengamatan aktivitas guru di siklus I berada pada kategori sangat baik dengan presentase nilai rata-rata $90 \%$. Aspek yang masih perlu ditingkatkan oleh guru dalam proses pembelajaran pada siklus 
I adalah selalu memberi semangat kepada siswa agar dapat meningkatkan keberanian siswa dalam menggunakan media pembelajaran kartu huruf. Hal ini disebabkan karena siswa belum terbiasa menggunakan media atau alat peraga dalam kegiatan pembelajaran.

Hasil pengamatan aktivitas siswa di siklus I berada pada kategori cukup dengan presentase nilai rata-rata $58 \%$. Hal itu disebabkan karena pada siklus I siswa belum terbiasa menggunakan suatu alat/media pembelajaran. Siswa juga belum terlalu baik dalam menjawab pertanyaan yang diajukan oleh seorang guru, membaca dan mengeja kata-kata, memperhatikan penjelasan materi dan masih bingung dalam menyimpulkan materi. Selain itu, masih ada beberapa siswa kurang aktif dalam mengikuti pelaksanaan pembelajaran.Untuk menindaklanjuti pembelajaran pada siklus II perlu ditekankan kepada siswa mengenai perhatian siswa terhadap kegiatan pembelajaran.

\section{Hasil Analisis Tindakan Siklus 1}

Setelah selesai pelaksanaan pembelajaran tindakan siklus I melalui pembelajaran membaca permulaan siswa menggunakan media kartu huruf, kegiatan selanjutnya adalah pemberian evaluasi akhir tindakan kegiatan siswa kelas I SDN Pakis. Secara ringkas hasil analisis tes siklus I dapat djelaskan sebagai berikut :

Hasil Analisis yang diperoleh :

Ketuntasan Belajar Klasikal adalah 13 siswa atau 13/25X 100\% $=52 \%$

Dari 25 siswa yang mengikuti tes akhir siklus I terdapat 12 orang yang memperoleh nilai kurang dan 13 orang yang memperoleh nilai baik dengan nilai rata-rata 69. Data ini menunjukkan bahwa pembelajaran membaca permulaan belum memenuhi batas tuntas yang ditetapkan. Dengan demikian pada tes akhir siklus I ini pembelajaran membaca permulaan dapat dikatakan belum mencapai tujuan yang diharapkan. Hasil ini memberikan pengertian bahwa ketuntasan belajar masih belum terpenuhi karena hasil belajar dapat dikatakan tuntas apabila mencapai 70 dan presentase ketuntasan klasikal mencapai $70 \%$.

\section{Refleksi Siklus I}

Berdasarkan hasil observasi dan evaluasi dapat diketahui bahwa masih ada beberapa siswa yang kurang aktif dalam kegiatan pembelajaran. Untuk menindaklanjuti pembelajaran pada siklus II perlu ditekankan kepada siswa mengenai perhatian siswa terhadap kegiatan pembelajaran.

Pada kegiatan pembelajaran siklus I masih ada beberapa siswa yang ragu- ragu menggunakan alat peraga/media, hal ini karena siswa belum terbiasa menggunakan peraga/media dalam kegiatan pembelajaran. Untuk mengatasi hal ini pada siklus II, guru berusaha untuk meningkatkan keberanian siswa melalui alat peraga terutama untuk menarik perhatian digunakan kartu huruf berwarna yang disertai dengan gambar.

\section{Siklus II}

Pelaksanaan siklus II hampir sama dengan pelaksanaan tindakan siklus I, yaitu membuat rencana pelaksanaan pembelajaran (RPP), menyiapkan alat dan bahan ajar serta instrument penelitian yang meliputi evaluasi akhir tindakan, lembar observasi kegiatan guru dan siswa.

\section{Hasil Observasi Aktifitas Guru dan Siswa Siklus II}

Hasil observasi pada siklus II dapat dideskripsikan bahwa siswa telah aktif dalam mengikuti pembelajaran sehingga terlihat adanya peningkatan. Semua siswa semakin antusias dalam mengikuti kegiatan pembelajaran. Dalam proses pembelajaran pada siklus II, kegiatan guru telah menunjukkan semua aspek berada pada kategori sangat baik. Begitu pula pada aktivitas siswa siklus II berada pada kategori baik dalam proses pembelajaran. Hal ini berarti taraf keberhasilan aktivitas siswa menurut pengamat pada tiap pertemuan mengalami peningkatan.

Berdasarkan perolehan pada siklus II kegiatan observasi yang dilakukan oleh observer dengan menggunakan alat peraga/media kartu huruf dalam kegiatan membaca permulaan siswa telah mencapai $98 \%$ berada pada kategori sangat baik. Hasil aktivitas siswa dalam proses pembelajaran siklus II telah berada pada kategori baik dengan presentase nilai rata-rata $89 \%$. Berdasarkan data hasil analisis di atas, dapat disimpulkan bahwa dari 25 siswa terdapat 23 siswa yang memperoleh nilai standar ketuntasan di 
atas atau sama dengan 70, sedangkan yang memperoleh nilai di bawah 70 adalah sejumlah 2 siswa, dengan rata-rata hasil belajar secara keseluruhan sebesar 92\%. Artinya, hasil belajar siswa sudah mencapai target seperti pada indikator yang diharapkan yaitu secara klasikal siswa dikatakan berhasil belajar apabila $70 \%$ dari jumlah siswa.

\section{Hasil Analisis Tindakan Siklus II}

Pembelajaran pada siklus ini adalah menggabungkan dan membaca huruf menjadi kata dan kalimat sederhana.. Setelah selesai pelaksanaan pembelajaran tindakan siklus II melalui pembelajaran membaca permulaan siswa menggunakan media kartu huruf, kegiatan selanjutnya adalah pemberian evaluasi akhir tindakan kegiatan siswa kelas I SDN Pakis.

Secara ringkas hasil analisis tes siklus II dapat dijelaskan sebagai berikut: Ketuntasan Belajar Klasikal adalah 23 siswa atau $23 / 25 \times 100 \%=92 \%$

Dari hasil pelaksanaan tindakan di siklus II dapat diketahui bahwa dari 25 siswa yang mengikuti tes akhir terdapat 23 siswa yang telah mencapai batas tuntas yang telah ditetapkan dengan nilai tertinggi yaitu 100 dan nilai terendah yaitu 58,33. Data ini menunjukkan bahwa pembelajaran membaca permulaan sudah memenuhi batas tuntas yang ditetapkan. Berdasarkan hasil tersebut dapat diketahui bahwa nilai rata-rata maupun ketuntasan klasikal tes kemampuan membaca permulaan yang dicapai siswa telah memenuhi indikator kinerja.

\section{Refleksi Tindakan Siklus II}

Berdasarkan hasil dari evaluasi/tes akhir, lembar observasi guru dan siswa pada siklus II ini dapat disimpulkan bahwa tindakan yang dilakukan telah maksimal. Siswa merasa senang dan antusias dalam mengikuti pembelajaran karena dengan penerapan media yang menarik anak tidak merasa bosan dalan kegiatan pembelajaran seperti kegiatan bermain. Sebagian besar siswa sudah dapat membaca huruf, suku kata, kata, dan kalimat sederhana dengan lancar serta penggunaan lafal yang benar. Siswa semakin tertarik untuk belajar membaca karena mereka menyadari bahwa pembelajaran membaca merupakan hal yang sangat penting. Siswa telah mengetahui bahwa untuk dapat mempelajari mata pelajaran yang lain terlebih dahulu harus mampu membaca. Untuk itu siswa selalu didorong untuk rajin belajar membaca, agar mereka mampu dan gemar membaca.

\section{Pembahasan}

Berdasarkan penelitian kurang maksimalnya aktivitas guru maupun siswa dalam proses belajar mengajar sangat terlihat pada hasil belajar siswa. Hasil belajar merupakan salah satu ukuran berhasil tidaknya seseorang setelah menempuh kegiatan belajar di sekolah dengan menggunakan penilaian berupa tes. Hasil belajar mempunyai peran penting dalam proses pembelajaran. Proses penilaian terhadap hasil belajar dapat memberikan informasi kepada guru tentang kemajuan siswa dalam upaya kegiatan pembelajaran selesai dilakukan.

Berdasarkan data yang diperoleh pada siklus I, dapat dikatakan bahwa penelitian ini belum berhasil karena masih ada 12 siswa yang belum mencapai batas ketuntasan. Hasil rata-rata tes kemampuan membaca permulaan siswa pada siklus I sebesar 69 dan ketuntasan belajar secara klasikal yaitu $52 \%$. Hasil ini belum memenuhi batas minimal indikator kinerja yang ditetapkan.

Hasil rata-rata tes kemampuan membaca permulaan siswa pada siklus II sebesar 78,67. Dilihat dari nilai batas minimal sesuai dengan indikator kinerja, nilai rata-rata siswa tersebut sudah memenuhi kriteria. Secara individual, dari hasil tes pada siklus II dari siswa yang berjumlah 25 orang yang telah mencapai nilai lebih besar atau sama dengan 70 sebanyak 23 siswa. Sementara 2 siswa mendapatkan nilai di bawah 70. Jadi, nilai tes kemampuan membaca permulaan siswa pada siklus II telah mencapai batas tuntas yang telah ditetapkan dengan tingkat ketuntasan belajar secara klasikal sebesar $92 \%$.

Peningkatan aktivitas selama kegiatan pembelajaran dapat dilihat berdasarkan hasil observasi yang meliputi kegiatan-kegiatan: aktivitas siswa dalam mengikuti pelajaran, keaktifan siswa dalam mengajukan dan menjawab pertanyaan, rasa ingin tahu dan keberanian siswa meningkat, kreativitas dan inisiatif siswa meningkat serta aktif mengerjakan tugas.

Kemampuan siswa bertambah meningkat dari siklus I, dan siklus II karena siswa pada saat 
pembelajaran menggunakan alat peraga/media merasa terangsang untuk mempelajari, mengamati, dan mencoba apa yang dilihat dan mudah untuk diketahuinya, anak lebih terfokus karena siswa merasa apa yang dilihat itu memudahkan untuk diikuti, mudah untuk meniru dan melakukan sesuai dengan petunjuk guru.

Hasil penelitian tindakan kelas tentang pembelajaran membaca permulaan melalui penerapan media kartu huruf yang dilakukan sebanyak dua siklus selalu mengalami peningkatan dan telah dapat mencapai batas tuntas sesuai dengan indikator kinerja yang telah ditetapkan. Dengan demikian, penelitian tindakan kelas yang dilaksanakan telah sesuai dengan tujuan yang diharapkan, yakni dapat meningkatkan kualitas proses pembelajaran serta kemampuan membaca permulaan siswa.

\section{Penutup}

Berdasarkan data hasil penelitian ini maka kesimpulan yang diperoleh bahwa hasil belajar siswa pada siklus I dalam peningkatan kemampuan membaca permulaan siswa memperoleh nilai rata-rata sebesar 69 dengan ketuntasan belajar secara klasikal 52\% dan hasil belajar siswa pada siklus II dalam peningkatan kegiatan membaca permulaan siswa dengan menggunakan media kartu huruf mengalami peningkatan dengan memperoleh nilai rata-rata 78,67 dan ketuntasan belajar secara klasikal sebesar 92\% dan telah memenuhi batas pencapaian indikator keberhasilan.

\section{Daftar Pustaka}

Depdiknas. (2004). Penilaian. Jakarta: Departemen Pendidikan Nasional.

Faizalnizbah (2013). Pengertian membaca. Tersedia: http://faizalnizbah.blogspot.sg/2013/08/pengertianmembaca.html [6 Januari 2014]

Haryanto, S.Pd (2012). Pengertian Media Pembelajaran. Tersedia: http://belajarpsikologi.com/pengertianmedia-pembelajaran/ [6 Januari 2014].

Hudaita (2009) Pembelajaran Membaca Permulaan Tersedia http://hudaita.blogspot.com/2009/01/pembelajaran-membaca-permulaan dengan.html/ (Diakses 05 Januari 2014)

Mbah Brata (2009). Pembelajaran membaca permulaan Tersedia: http://mbahbrataedu.blogspot.com/2009/08/pembelajaran-membaca- permulaan-melalui.html/ (Diakses 05 Januari 2014)

Muhammad faiq (2013). Instrumen untuk menilai media pembelajaran berbasis teks. Tersedia : http://penelitiantindakankelas.blogspot.com/2013/10/contoh-instrumen- untuk-menilai-mediapembelajaran-berbasis-teks.html [7 januari 2014]

Paud Stai Al Gazali Bone (2013). Pengertian membaca permulaan. Tersedia : http://paudstaialgazalibone.blogspot.com/2013/04/pengertian-membaca- permulaan.html (7 januari 2014)

Puji Santosa, dkk (2005). Materi dan Pembelajaran Bahasa Indonesia . Jakarta : Universitas Terbuka

Slamet Hariadi (2013). Pengertian cara dan makna membaca Tersedia http://selamethariadi.com/pengertian-cara-dan-makna-membaca/ [6Januari 2014]

Teguh Prasetyo (2009). Pembelajaran membaca dan membaca permulaan. Tersedia : http://teguhsatu.blogspot.com/2009/11/pembelajaran- membaca-dan-membaca.html [7 Januari 2014]

http://gudangartikels.blogspot.com/2011/08/pengertian-dan-tujuan-membaca- permulaan.html (Diakses Tanggal 10 Januari 2014)

Suhadinet, "Langkah-Langkah PTK Menurut Kemmis dan McTaggart" http://suhadinet.wordpress.com/2009/06/08/langkah-langkah-ptk-menurut- kemmis-dan-mctaggart/ (Diakses 13 Agustus 2013). 